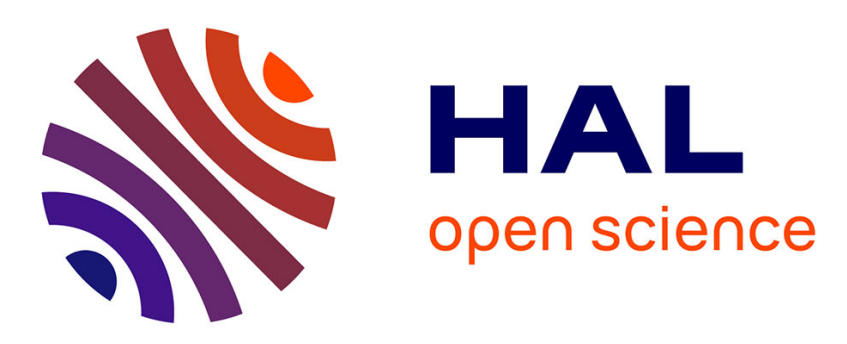

\title{
Search for oblique Whistler waves using solar orbiter data
}

Lucas Colomban, Matthieu Kretzschmar, Volodya Krasnoselskikh, Laura Berčič, Chris Owen, Milan Maksimovic

\section{- To cite this version:}

Lucas Colomban, Matthieu Kretzschmar, Volodya Krasnoselskikh, Laura Berčič, Chris Owen, et al.. Search for oblique Whistler waves using solar orbiter data. vEGU21, 2021, Online, France. 10.5194/egusphere-egu21-16006 . insu-03559281

\section{HAL Id: insu-03559281 https://hal-insu.archives-ouvertes.fr/insu-03559281}

Submitted on 7 Feb 2022

HAL is a multi-disciplinary open access archive for the deposit and dissemination of scientific research documents, whether they are published or not. The documents may come from teaching and research institutions in France or abroad, or from public or private research centers.
L'archive ouverte pluridisciplinaire HAL, est destinée au dépôt et à la diffusion de documents scientifiques de niveau recherche, publiés ou non, émanant des établissements d'enseignement et de recherche français ou étrangers, des laboratoires publics ou privés.

\section{(ㄷ)(1)}

Distributed under a Creative Commons Attribution| 4.0 International License 
EGU21-16006

https://doi.org/10.5194/egusphere-egu21-16006

EGU General Assembly 2021

(c) Author(s) 2022. This work is distributed under

the Creative Commons Attribution 4.0 License.

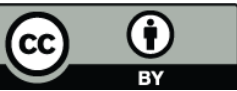

\section{Search for oblique Whistler waves using solar orbiter data}

Lucas Colomban, Matthieu Kretzschmar, Volodya Krasnoselskikh, Laura Bercic, Chris Owen, and Milan Maksimovic

LPC2E (CNRS), Loiret (45), France (lucas.colomban@cnrs-orleans.fr)

Whistler waves are thought to play an important role on the evolution of the electron distribution function as a function of distance. In particular, oblique whistler waves may diffuse the Strahl electrons into the halo population. Using AC magnetic field from the RPW/SCM (search coil magnetometer) of Solar Orbiter, we search for the presence of oblique Whistler waves in the frequency range between $3 \mathrm{~Hz}$ and $128 \mathrm{~Hz}$. We perform a minimum variance analysis of the SCM data in combination with the MAG (magnetometer) data to determine the inclination of the waves with respect to the ambiant magnetic field. As the emphasis is placed on the search for oblique whistler, we also analyze the RPW electric field data and the evolution of the electron distribution function during these Whistler events. 